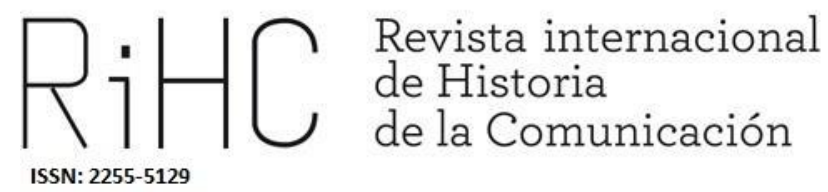

\title{
THE TRANSITION. CONVERGENCE AND DISCREPANCY IN THE INTERNATIONAL AND NATIONAL PRESS COVERAGE OF SPAIN'S MAJOR POSTWAR INTERNATIONAL NEWS EXPORT $^{1}$
}

DOI: http://dx.doi.org/10.12795/RiHC.2018.i11.02

Recibido: 03/10/2018

Aceptado: 08/11/2018

Publicado: $15 / 12 / 2018$

Christopher David Tulloch ORCID (iD https://orcid.org/0000-0002-5476-0887 Universitat Pompeu Fabra, christopher.tulloch@upf.edu

Jaume Guillamet Lloveras ORCID (iD https://orcid.org/0000-0001-8385-1588 Universitat Pompeu Fabra, jaume.guillamet@upf.edu

\footnotetext{
${ }^{1}$ Los resultados presentados en este artículo corresponden a los proyectos de investigación "Noticias Internacionales de España. la Transición" (CSO 2009-09655), "El papel de la prensa diaria en la Transición" (CSO 2012-36774) y "El papel de la prensa no diaria en la Transición" (CSO 2015-67752-P) 
Resumen: El papel de la prensa nacional y extranjera en la cobertura informativa de la Transición española a la democracia (1975-1978) ha sido una referencia constante en la historiografía del período de cambio político en España tras el final de la dictadura de Franco, así como en la cultura periodística. En este artículo presentamos los resultados generales de tres proyectos de investigación sobre el papel de la prensa extranjera, de la prensa diaria española y de la prensa no diaria enlos que se pueden comprobar convergencias y discrepancias en el relato informativo, las valoraciones editoriales y los posicionamientos políticos. La mayor independencia y libertad informativa de la prensa extranjera contrasta con la proximidad de la prensa española al rey y al gobierno, con la excepción del apoyo crítico a la reforma de las nuevas revistas políticas y los diarios surgidos en los primeros meses del proceso de cambio político.

Palabras clave: Transición española, corresponsales extranjeros, prensa diaria, revistas políticas, periodistas

\begin{abstract}
The role of the national and foreign press in the news coverage of the Spanish transition to democracy (1975-1978) has been a constant reference in the historical study of the period of political change after the end of the Francoist dictatorship. In this article we present the general results of three research projects concerning the role of the foreign press, of the Spanish daily press and the magazine marketin which we can observe both convergence and discrepance in the news narrative, editorial behaviour and political standpoints. The greater independence and informative freedom of the foreign press contrasts with the proximity of the Spanish press to both King and government with the exception of the critical support to reform expressed in both the new political magazines and newspapers during the first few months of the process of political change.
\end{abstract}

Keywords: Spanish Transition, foreign correspondents, daliy press, political magazines, journalists

\title{
Introduction
}

Transition studies is undoubtedly a growing field within international political science. Interested scholars can access key texts that cover the external stimulation of democracy and the context of regime transition (Pridham, 1991, McGrew 1997) along with comparative works concerning democratic regeneration in Latin America, South Africa, Russia and Eastern Europe (Filgueira and Nohlen 1994; Anderson, 1999; Jones 2001; Gross 2004; Voltmer 2006). In this sense, the post-Francoist Spanish transition to democracy is no exception as the abundant literature available on the subject illustrates (Carr and Fusi, 1993; Maravall 1982; Preston 1986; Clark and Haltzel 1987; Tuñon de Lara 1991; Tusell 1996, 1999; Soto 1998; Townson 2007). Within the wider field of transition studies, the role of the press in political change is itself an emerging field in journalism history studies. In that sense, the specific contribution of both the international press (Tulloch 2015; Guillamet 2016) and local journalists (Barrera, 1995; 
Zugasti 2008, Quirosa-Cheyrouze 2009; Guillamet 2018) in the conquest of political liberties and the consolidation of a democratic system in Spain are salient examples of these press/power dynamics.

This paper attempts to draw together preliminary conclusions regarding the three consecutive research projects led by the Journalism Research Group at the Pompeu Fabra University in Barcelona focussed on the role of the international and national press as well as national and international weekly magazines during the Spanish transition to democracy in the late 1970s. The first project (2010-2012) focussed on the foreign correspondents and included field work in London, New York, Paris, Rome and the national archives as well as interviews with former journalists. Results were presented at IAMCR Durban 2012. The second project (2013-2015) shed light on the role of the national daily press and included exhaustive data retrieval and ethnographic work with leading journalists and politicians at the time, results of which were posted at IAMCR Montreal 2015. The third project (2016-2018) has worked on the political and general information magazines both in Spain and abroad. Some partial results of this Project were presented at IAMCR Leicester2016 and Cartagena de Indias 2017. The initial general results of this latest project -presented for the first time at IAMCR 2018- allow us to begin to draw across-the-board conclusions based on the results of all three studies.

In order to attempt to extrapolate wider and cross-comparative ideas and given the limited nature of the space available, the authors discarded a lineal project-by-project approach in favour of an analysis of five key issues -the passing of Franco, the debut of King Juan Carlos, the first Suarez government, the legalization of the Spanish Communist Party and the result of the first free elections- which dominate the early part of the Transition (November 1975 to June 1977) and which are clearly and constantly present in the three fields of journalistic production -international press, local newspapers and magazines- under analysis here.

\section{The Francoist legacy: condemned in the foreign press, respected on the pages of national dailies}

One of the most glaring discrepancies between the coverage of the international and the national press of the Spanish transition to democracy is their initial reaction to the 
death of Franco and retrospective analysis of his regime. As a general rule, the foreign press takes no time in framing Francoism as undeniably negative and his dictatorship as the illegitimate continuity of the Civil War. The Italian press sets the tone. Less than 24 hours after his death, Alberto Viali in La Stampa refers to his rule as a "crazy, Nazistyle" dictatorship. Carles Casalegno in the same paper speaks of an end to "forty years of absolute power built on one million dead". French daily Le Figaro openly doubts that the end of the dictatorship means the immediate beginning of freedom. Walter Haubrich, in the Frankfurter Allgemeine Zeitung (FAZ) condemns Franco for his cruel attacks both on liberalism as well as communism. The Munich-based Suddeutsche Zeitung (SZ) writes that towards the end of his regime the "isolated dictator" had returned to his "fascist origins" and shown a genuine incapacity for preparing the arrival of a democracy. The New York Times (NYT) acuses Franco of committing "atrocious reprisals" and of governing through terror and its Spain correspondent Henry Giniger spoke of a man who "when in doubt, repressed". The NYT editorial entitled "hated by many, loved by few", published the day after Franco's death, summarises the papers position. An interesting exception to the rule is the British press which shows itself to be more benevolent towards Franco. In spite of criticism regarding the nature and resistance to change of his regime both The Times and The Daily Telegraph speak of his successful military career, his independent stance during the Second World War and the prolonged period of peace and political stability enjoyed by Spain in recent decades. The latter even goes as far as saying that the Spanish people will suport Prince Juan Carlos because they are "anxious to conserve and construct the prosperity reached under the firm and stable government of Franco". (Guillamet 2016: 47-49)

For obvious reasons related to issues of censorship and press control -the 1966 Press Law is still firmly in place- and newsroom inertia of so many years of strict supervision, Spanish national newspapers offer a contesting portrayal of the legacy of Franco. In the days following his death, there is a tone of widespread approval for a regime normally couched in terms of the 'modernization' and 'guarantee of national unity' which his rule had represented. For $Y a, A B C$ and to a slightly lesser extent, Informaciones, it is time for grieving and for the recognition of the figure of the dictator. The op-ed content during the first seven days following his death constitutes one constant tribute to Franco. While Informaciones publishes four consecutive editorials on Franco before turning its attention to the new King, $Y a$ offers no less than six editorials about his role in contemporary Spanish history and a uniformly positive reading of his political testament. The Catholic daily refers to Franco as "the great Spanish figure of the $20^{\text {th }}$ century" whose mark on Spanish society is "so huge that any superlative would only reduce it". Ya also considers that Franco not only paved the way for the Transition but is also directly responsible for the popularity of the new Monarch when stating that "Franco has won his last battle which was to offer the masses to the King so that the Monarchy will not have to build itself in a vacuum but 
rather on the grounds of popular adhesion" (Tulloch, 2017: 91). $A B C^{\prime}$ 's lauding of the figure of Franco goes beyond the first few days and weeks and continues into months. In May 1976, and coinciding with the six month commemoration of his death, the Madrid daily still openly revindicates the "common historical patrimony" that Franco represents. On November $20^{\text {th }} 1976$, -exactly a year after his death- the paper offers a full length editorial recalling the figure and legacy of the dictator. Outside of the capital, on the day following his funeral, the publisher of La Vanguardia Española in Barcelona, the Count of Godó, offers a full length article in which he exalts the figure of Franco and declares himself to be proud to have formed part of the Spain he forged. After a few days, La Vanguardia left behind references to the legacy of the dictator in favour of clear support to the King.

The reaction of the Spanish magazines was more varied given that some such as Cuadernos para el Diálogo, Triunfo or Cambio 16 had already emerged on the newsstands with an attitude clearly favourable to political change unlike others such as Gaceta Ilustrada or La Actualidad Española which were tied to the main newspapers and thus showed themselves to be more benevolent in their treatment of Franco.

The Anglo-American political weeklies analysed in this study -The Economist, Time and Newsweek- while as equally critical of the Francoist legacy as their daily newspaper counterparts, tend towards a double analysis of how his death may affect institutions such as the Armed Forces while at the same time offering projections about the consequences of the changes ahead. The Economist expresses its relief at the passing of what it calls on its front cover "Spain's little old man" but also refers to the King as the "Prince-in-waiting so few people know" ad gives tips on "how to exorcise Franco's ghost". Time in a long six page retrospective talks of "36 years of iron rule" and in articles which reflect the political uncertainty at the time publishes pieces entitled "After Franco, hope and fear" or "Juan Carlos: the Uncertain King". Newsweek also carries out this double coverage combining a moderately negative look back at the Francoist years accompanied by doubts about the political future of Spain as can be seen by the content of articles such as "Waiting in the wings" or "Deathbed Politics". 


\section{The King's first twelve months: from widespread criticism to full support of pro-democratic measures in both international and national press}

While Transitionist literature has been extremely favourable towards the figure of Juan Carlos I, one of the most interesting transversal observations of the coverage carried out by international press, national dailies and magazines at the time refers to the reservations shown by all alike regarding the capacity of the young Monarch to carry out plans for reform and to lead Spain into a new political future. Unlike the discrepancies between the foreign press and national newspapers regarding the figure of Franco, the young King is the subject of across-the-board criticism in the first few months of his reign.

The international press is disappointed at the Monarch's opening moves. To begin with, the King is widely portrayed as the heir to Franco -Giscard d'Estaing had coined Juan Carlos I "a prefabricated King" - who does not represent a break with the past. The Suddeutsche Zeitung urged the King to act quickly so as not to lose credibility (24 Nov 75) The nomination of Torcuato Fernández Miranda as president of the Kings Council is seen as a gesture to the extreme right and is openly criticised in the NYT (3 Dec 75). With the exception of the Daily Telegraph and the Washington Post, the foreign press is frustrated by the nomination of Arias Navarro as Prime Minister. The NYT warns the King of choosing the "continuation of Francoism without Franco". (10 Dec 75) Haubrich in the FAZ says that this first cabinet does not correspond to that desired by Spanish democrats. The NYT accuses the King of "not operating with courage" (23 Dec 75) while La Stampa is furious at the exaltation of Franco in the King's Christmas message (27 Dec 75).

The continuist policies of Arias Navarro are received with disappointment by foreign correspondents. Reforms are considered to be too slow and the spring of 1976 presents unrest in Catalonia, the Basque Country and the arrest of political opposition. Arias Navarro is interviewed by Arnaud de Borchgrave in Newsweek and his immobilist philosophy only generates greater frustration (5 Jan 76). The Times accuse the King of "not putting his weight behind change" (31 Mar 76) and the Corriere della Sera (15 Mar 76) points towards Arielza and Fraga as immediate solutions. Sandro Viola en La Repubblica states that Juan Carlos' Spain is "practically the same as under Franco" (3 April 76) and Le Figaro states that Juan Carlos' desire for change is challenged by Arias' desire to perpetuate the Francoist heritage. (20 April 76) On 26th April Newsweek provides Arias Navarro's political death sentence when revealing how the King has referred to his premier as an "unmitigated disaster". 
As for national titles, even the staunchly pro-monarchist La Vanguardia Española, while welcoming the arrival of the King as a sign of democratic regeneration, complains of the apparent lack of distribution of power. The creation of the necessary conditions for the conversion of Spain into a modern European state seemed to be hindered by the lack of measures taken for the provision of such a change. While -as in the case of the death of Franco- the international press is much quicker to oppose Arias Navarro than their national counterparts, that does not mean the national press protected Arias Navarro from criticism. La Vanguardia, which had initially offered lukewarm support to Arias Navarro, begins to publish articles critical of both his economic policies and his close relations with the Franco nostalgics known as the "bunker". Ya is infuriated by the lack of communicative skills displayed by the premier in his first live televised speech at the end of January. By April the paper withdraws the support it had lent to Arias Navarro and both this paper along with Informaciones criticize his inability to face up to the far-right bunker and push the need for a democratic programme, a calendar for change and a timeline to make political reform a reality.

Arias Navarro's forced resignation comes as no surprise to both the international and national press. The Italian press celebrates the decision and now considers the King an artifice of change. The Times says the end of Arias Navarro puts an end to jokes about "Juan Carlos The Brief" and both Le Monde and the NYT say that 'resignation' is a euphemism and argue that it has been forced by the King. The real surprise will be the substitute.

While Arias Navarro's resignation on the $1^{\text {st }}$ of July was to change the dynamics of the coverage of the King in both the national and international press, the foundations for this about-turn were laid a month before coinciding with the King's visit to the United States in June 1976 for the bicentenary of US independence. The Kings speech at the US Congress is the launching pad for more favourable criticism particularly in the international press where reaction is glowing. The NYT proclaims Juan Carlos "a King for democracy" (4 June 76). Le Figaro talks of a "new image" for Spain and the SZ refers to the Monarch as "a King who, in the New World, has broken with the Francoist legacy". (8 June 76).

A similar effect is perceptible in the national press. From June onwards newspapers such as Informaciones and $\mathrm{Ya}$ reflect the Monarch as a symbol of the reconciliation needed to guide Spain through complex political times. The former dedicates no less than eight editorials to him throughout the second half of 1976 -along with a special edition on the $22^{\text {nd }}$ November 1976 dedicated to erasing Franco from the collective memory in favour of the King- while the latter also dedicates a special issue on the anniversary of his confirmation as Head of State. New titles on the newsstand such as 
El Pais -it appears just a month before the trip- are also enthused by Juan Carlos' reception in the US and see him the key to changing Spain's image abroad.

As for magazines, Time is equally enthusiastic and considers Juan Carlos to be "A New King with Clout" (7 June 76). Cambio 16 lends the Royal trip considerable coverage but, in a stark reminder of the austere conditions under which the national press was still force to manoeuvre, is threatened with suspension by the government for having published an image of the King apparently tap dancing on the front cover of the magazine. In this sense the possible reservations that the Spanish magazines may have had concerning the figure of the King are constrained by the protection lent to him by the Press Law. That said, all of them see the Monarch as the only figure capable of forcing reforms beyond the continuity of Francoism. The new democratic magazines insist in counterbalancing the figure of the King with that of Franco as well as the positive relationship he has with his father Juan de Borbón, son of Alfonso XIII and legitimate heir to the throne whose return was blocked by Franco.

\section{Suárez: from 'unwelcome surprise' to Transition figurehead}

The nomination of Suárez as prime minister knocked the international and national press out of their stride. Many foreign correspondents had laid their weight fully behind Areilza seen by the NYT as a figure who "has stopped fighting the Civil War and is now trying to pull the country away from its old antagonisms" (23 Dec 75) The national press also coveted Areilza as can be seen by its clear support even as late as May 1976 for his proposal of a national pact for reform and by the fact that he was clearly the minister most closely associated with the King. The weekly magazines gave him considerable space along with Fraga who offered lengthy exclusive interviews to the Angloamerican publications.

Along with the fallout of the exclusion of Areilza and Fraga, the widespread scathing criticism of the nomination of Suarez in the international press is largely due to him being received as another heir of the Regime. The French press is unanimous in its opposition to him. In the UK, the Financial Times says the choice of Suarez shows the weakness of the King and the political system he has inherited and criticises his youth, lack of experience and minimal contacts with the opposition The Guardian fears that Suarez could be worse than Arias. (10 July 76) The German press states that this decision shows that, despite cosmetic changes, Spain is still a regime. The Italian press considers him to be a Fascist imposition that will not last. 
Although couched in more moderate terms, the national press is in harmony with its international colleagues on this issue. Many Spanish papers considered the new Prime Minister not to have the political weight or democratic pedigree in order to carry out reforms. The choice of Suárez provokes a strongly worded editorial in La Vanguardia Española, a surprising reaction given the King's open support for him. The traditionally moderate daily questions not only the capacity of the politician to bring Spain into the democratic era - "its possible that it's a good change, its probable that it isn't" - and considers this decision to represent a profound political crisis especially given that he did not dispose of a team especially after neither Areilza nor Fraga were to be named in the new Cabinet. The composition of the first Suarez Cabinet was considered to be made up of second string politicians. Informaciones wrote at the time that "the absence of first rate political figures and the relative anonymity of many of its components contribute to fostering doubts and suspicions" (Zugasti 2007: 71). El Pais explained that as journalists read through the list of names, the most frequent question in the newsrooms was "Who's he?" Delkader at El Pais remembers that "the antecedents of Adolfo Saurez were not the cleanest slate for transforming the regime" (Zugasti 2007: 70). This newspaper was of course responsible for publishing the most damning criticism of the new government. Ricardo de la Cierva's piece entitled "What a mistake, what an immense mistake!" where he refers to the "first Francoist government of postfrancoism" forms part of Transition folklore regarding the press' reception of Suárez. To back its arguments, the next day the paper publishes a full page spread of the criticism of the Suarez cabinet in the international press.

$A B C$, while more complimentary in its tone towards Suàrez at the beginning -largely due to his proximity to the King-cannot comprehend the absence of Areilza and Fraga and consequently talks of a government without leaders while gradually withdrawing support for the new leader. Ya considers Suarez's time in the Movimiento as a negative sign for the consolidation of genuine democratic change. According to a staff writer at the time, "while it is true that the "what a mistake" article was written by de la Cierva we all thought it to be true" (Tulloch 2017: 95). Ya considers his nomination as a "victory for the prudent reformists" and suggests the opposition take note and start to renew their leaders given the clear empathy between the King and the PM. Informaciones is equally surprised by the choice and considers Suarez's background in the Francoist rank and file to be an obstacle and "an unfavourable starting point".

The only clear exception to the rule is the favourable reaction of the far-right newspaper El Alcazar. This publication sees Suarez as "one of their own"; a former black shirt figure from the rank and file of the Movimiento who should be able to out and end to the reform process. The paper goes on to urge Suarez to tackle the economic crisis before unveiling any political reforms and reminds the new premier that he represents a generation fully able to enjoy the 'peaceful' years brought by Francoism. Not surprisingly El Alcazar was one of only two papers -ABC was the other- 
to reproduce the King's message to his government in its first formal meeting: "this must be a strong government in a strong State".

As for the magazines, the Anglo-American publications tend to stress the "change" factor over and above any extended direct criticism of Suarez himself. Time magazine employs the headline "Time for a change" when referring to his nomination while Newsweek talks of "Changing the Guard" (12 July 76) and, a week later, refers to the new premier as "The Kings Man" (19 July 76). Time declares that Suarez has forced the Spanish to "enter into an unprecedented national dialogue about democracy" (16 Aug 76) and describes Suarez as "a unique political phenomenon".

It goes without saying that over the coming months both the international press and local journalists warm to the media-savvy Suárez as measures such as the first political amnesty, the announcement of a referendum on political reform, the return of the exiles and the calling of free elections in June 1977 are made. All the publications refer to the fact that Suarez represents a generational break with the generation of the War and despite the initial reservations highlighted above, he slowly gains the recognition of the international and press alike and is widely portrayed as a reformer who aims to lead Spain into Europe. At a national level some papers are more enthusiastic then others- $Y a$ and $A B C$ lead support for him- as he becomes the figurehead of political centrism the UCD and Christian democracy while after these initial doubts, Suarez is generally praised by the foreign press and especially by the magazines. In general terms, Newsweek presents Suarez as a "miracle worker who dragged Spain out of the dictatorship" (17 Apr 77) and Time considers him to exercise undeniable leadership. The article entitled "The Royal Favourite", published just a month before the June 15 elections, sums up the magazines' position towards a politician who "was the executor of the Transition of post-Francoist Spain... many voters prefer to vote for a man than a cause especially for an attractive candidate who they know and have learnt to trust..." (16 May 77) The exception to the rule here came from the Spanish democratic-era magazines such as Cuadernos, Cambio 16, Triunfo which, while accepting his capacity to carry reforms constantly, highlighted the personal contradictions of the former Francoist. The traditional magazines however, lent him their inconditional support.

To sum up, Suarez is seen as the only actor in the turbulent Spanish landscape capable of taking Spain towards the political Centre, an ideological space considered by the US and the UK as ideal for consolidating the democratic project and for cultivating transatlantic relations. According to Fernandez-Cuesta, one of the reasons for the positive image of Suarez in the foreign press is that "from the beginning of his mandate, he showed a clear disposition to meet up with the correspondents of the main foreign media accredited in Madrid... he became a front cover political figure in the European and American press because he never showed disdain towards their delegates in Spain" (Tulloch 2014: 101). 
It goes without saying that over the coming months both the international press and local journalists warm to the media-savvy Suárez as measures such as the first political amnesty, the announcement of a referendum on political reform, the return of the exiles and the calling of free elections in June 1977 are made. All the publications refer to the fact that Suarez represents a generational break with the generation of the War and despite the initial reservations highlighted above, he slowly gains the recognition of the international and press alike and is widely portrayed as a reformer who aims to lead Spain into Europe. At a national level some papers are more enthusiastic then others- $Y a$ and $A B C$ lead support for him- as he becomes the figurehead of political centrism the UCD and Christian democracy.

\section{Legalization of the PCE: welcomed by the foreign press, tolerated at home}

The legalization of the Spanish Communist Party (PCE) fascinated the international press in different ways and Carrillo was often addressed as the leader of the antifrancoist opposition ready to come to Spain for national reconciliation and in this sense is interviewed in Paris by both Time and Newsweek in November 1975. His detention in Madrid in December 1976 injects greater tension into the story and is seen as a litmus test for Spanish democracy. While for the European press the story was framed within the wider context of Eurocommunism and Carrillo's alliance with Berlinguer and Marchais, for the US press, Carrillo's critical stance towards Soviet communism allowed the PCE story to enter into a larger Cold War narrative. The EuroCommunist summit in March 1977 in Barajas is amply covered by the international press as the counterbalance to the Warsaw Pact countries. The Telegraph urges the Italians, French and Spanish to break with Moscow and points out that Carrillo is the most combative figure of the three. The Financial Times interprets the summit as the proof of PCE's choice of a democratic road map. When the party is finally legalized on April $9^{\text {th }}$, Le Monde reflects the disgust of the military, the FAZ considers the move fundamental to the credibility of the Suárez project and the Italian press puts its satisfaction on hold while waiting for the reaction of the military. Bugialli of the CDS calls it Carrillo's "longest night" and the "most decisive step made by Suarez for the credibility of his democratic project". The NYT talks of the fall of the "last barricade" and the Telegraph defines the legalization move as the most decisive proof of the break with Francoism".

The vision of the foreign correspondents contrasts with that of the national press for which the PCE issue is fundamentally about stability and internal order. That said and 
in line with their international colleagues, initial concerns in early 1976 turn to a genuine lobby by the spring of 1977 for the party's legalization including even the most conservative dailies such as $\mathrm{Ya}$ which while not trusting Carrillo, considers legalization preferable to forcing the party to act in clandestine fashion which may conversely lead to the party attracting more followers. The decision to legalize the PCE is seen as an act of "political prudence" and its position is clearly defined in the editorial "No to Communism, Yes to the legalization of the PCE". (20 Apr 77) Informaciones respects the moderate and respectful manner in which PCE has carried out its electoral campaign while La Vanguardia warns the party to follow the rules and in a stern editorial, published some days later, reminds its readers that "it is incompatible to declare oneself monarchic and loyal to the Crown while at the same time encouraging political currents which may end in sedition". (Rodriguez-Martinez et al: 611) The legalization of the PCE was accepted by the democratic-era magazines not just as a measure of support for Suarez -as in the case of the majority of newspapers- but was a systematic petition made since their founding as an indispensable condition for real democratic reform.

However, there is no complete consensus on the issue. $A B C$ opposes legalization even after the decision has been made arguing that such the approval of the PCE is not a requisite for a stable democracy. The measure is written off as a "grave decision and error" -in line with a similar stance taken by the hierarchy of the armed forces- and the paper chooses not to join the common editorial signed by all Madrid dailies. It goes without saying that nostalgic dailies such as El Alcazar were radically opposed to legalization.

One final point should be made here: while it its true that throughout 1976 and the spring of 1977 it is clear that the national and international press coverage of the PCE is tailored almost in exotic terms by the fact that the party is never perceived as a threat to the conservative centre right party lead by Suárez. Once the party enters the electoral lists on April $15^{\text {th }}$ the tone of the coverage is decidedly more aggressive in order to booster the chances of the centrist options.

\section{Elections June 1977: international and national press consensus on the 'ideal result' of the first democratic vote}

The first democratic elections in 41 years culminate the first 18 months of the Transition process. The Financial Times and the Telegraph plead with Suarez to present 
his candidacy as "the best hope for the continued progress" of Spain. Kasseber in the Suddeutsche Zeitung says that never did he dream that just one and a half years after the death of Franco, Spain would be celebrating such elections and begs Suarez to be more involved in the UCD campaign to assure victory. The foreign press are captivated by the new actors on the Transition political stage such as La Pasionaria whose arrival at Madrid airport is amply covered by the correspondents who turned up to see her return or Felipe Gonzalez whom Haubrich at the $F A Z$ calls "the news star in the Spanish sky". The international press predict a Suarez victory. Niedergang of Le Monde reminds his readers that Suarez was the director of TVE and understands screen politics better than his rivals and La Stampa argues that Suarez will win because "a political centre is emerging which distances from long term fascism" and because Suarez is "intelligent, practical and acts as if he has no ideology at all". The British press is the only one to express a concern that if Suarez is the "king's candidate" and Suarez loses, he might take the King with him as happened with his brother-in-law Constantino of Greece. Gott in The Guardian says a victory for the Left will prove that republicanism remains as strong in Spanish politics as it was in the Thirties. The Telegraph, paraphrasing Churchill, calls the $15^{\text {th }}$ June "the end of the beginning".

The Suarez victory is received in ecstatic fashion by the foreign press. Romero in Le Figaro declares that "Spain has exorcised its old ghosts". The NYT says the result opens a period of hope and the possibility of culminating the democratic process. The Post considers the elections to be important because there was no violence and reminds readers that the campaign was more centred on leaders than on ideas. The Italian press congratulates Spain on its maturity and considers the result to bring Spain back into the western European fold. The German correspondents consider the result to bring about the end of the Civil War. As for the UK, the Telegraph makes a point of highlighting the PCE's "miserable results". The Times says the PCE's results will make life easier with the armed forces. The Guardian, delighted at the results, says that the Spanish have "buried their past under a mountain of ballot papers". There is general satisfaction at the poor results of Fraga's AP and the ultra conservative forces in general. The Guardian says the "heirs of Franco" have been reduced to a "small band of nostalgics". The FT says the result -AP even trailed the PCE- is humiliating, repudiates the Franco era and is a setback for those who wanted to take advantage of the violence in the spring of that year and the legalization of the PCE. The paper names Suarez "Man of the Week". The Times considers the King to be "the real winner of the elections" and the non-election of former PM Arias Navarro as senator as the best symbol of the failure of the "Bunker".

While the international press was waxing lyrical about the first free elections in historical and sociological terms, the national press was busy getting behind its candidates and parties. $A B C$ hedges its bets and publicly asks for the votes for the candidates of both the Alianza Popular and the UCD. La Vanguardia supports Suarez 
but demands solutions to the economic crisis. Ya considers that the elections put an end to twelve difficult months but thanks the King and the government for allowing the democratic game to be played out. With the elections over, both $A B C$ and $L a$ Vanguardia pay tribute to the winner and interpret the results as a nod to generational change symbolized by Suarez and Gonzalez. $Y a$ is a direct benefactor of the result as some of its contributors are in the first Cabinet. Informaciones points to the long road ahead and urges the winners to make pacts in the defence of democracy.

As for the magazines both the Economist and Newsweek go with the same headline to accompany their front cover stories: "Spain's center holds" (18 June 77) while Time goes with "Democracy wins". All pay tribute to the new media star that is Suarez who is spoken of in Newsweek as "Europe's newest Giscard".

\section{Observations on comparative analysis}

Space limitations have only allowed for the cross comparative analyses from almost 40 publications from the foreign and national press and their corresponding magazine markets to touch on just five of the salient issues from the first 18 months of the Spanish Transition timeline. That said, and having run through the press reaction in each case, certain transversal observations and the contemplation of additional wider issues which go beyond the scope of the specific news coverage itself can be made.

Convergence or discrepancy? It is clear that the level of coincidence depends on the nature of the news story itself. The international and the national press align in their reaction to Suarez's nomination as premier which is received with almost unanimous dismay, their doubts over the leadership capacity of the young King or in their support of measures for political renewal and democratization. There is a clear consensus for order and the pushing of a "stability agenda" albeit from different perspectives. While the international -and particularly the US- press focus their coverage on the Spanish transition within a wider framework of political instability marked by the fall of the military dictatorship in Greece, the "Carnation revolution" in Portugal or the context of left wing terrorism in Italy and Germany, the national press often expresses its concern regarding the position of the Armed Forces in the face of greater liberalization or the absence of a consolidated -and moderate- opposition party.

They are seen to be divided when analysing the Francoist legacy -largely due to the press restrictions placed on the local dailies but also on the inherent conservative nature of the papers on the newsstand in November 1975- or on issues such as terrorism in the Basque Country. While the tone of the national press towards the acts perpetrated by ETA is one of indignation, the international press -and in particular the 
on-the-ground feature articles in the influential Angloamerican weeklies- couches the organization in more lenient terms as a violent answer to a regime which executes its militants after war trials carried out with no legal guarantees. ETA is often portrayed by these publications as an organization which enjoys widespread popular support and is reinforced by ill-judged and indiscriminate police repression.

Fine-tuning the definition of 'national press'. Important caveats must be introduced into such cross-referential studies. One such observation is that wide-sweeping attempts to compare the international press with the national press must take into account the existence of two parallel press groupings in the case of the Spanish national press: the pre-Francoist news titles - La Vanguardia, $A B C$, Informaciones and $\mathrm{Ya}$ - and democratic era newspapers such as El Pais, Diario 16 or the Catalan daily Avui. A newsroom born in democracy does not inherit the internal dynamics of a publication forced to function under suffocating press restrictions for decades.

Nuances with the 'international press'. As with the national press, on some issues the foreign press does not speak with one sole voice. On occasions, the Angloamerican press is at odds with its European colleagues. Articles regarding the historical legacy of Franco or attitudes towards Carrillo and the PCE are pertinent examples of this trend. The PCE story is more comfortably managed by the European press within the wider context of Eurocommunism whereas for the US, the possible re-emergence of the Spanish Communist party is seen from a Cold War mindset.

Unequal working conditions of foreign and national journalists. Cross comparisons must take into account the working conditions under which the journalists were forced to operate and in many ways, the foreign correspondents had an advantage when covering the Transition. Leading Spanish politicians at the time -Arias Navarro, Fraga, Areilza, Carrillo- resorted to them when they wished to convey their messages and they were often treated better as part of the pro-democratization media handling strategy. In this sense, the international press could exploit the wider margin for manoeuvre unwillingly lent to them as a gesture of commitment to greater democratization. International reporters very often enjoyed direct access to sources and of course the foreign press corps was, to a large extent, freer from the restrictions on Spanish journalists. Foreign reporters were often used as a channel by local journalists to publish stories, to pass on ideas and thus circumvent local restrictions and as a cover participating in acts demanding greater press freedom.

Whilst surveillance measures -phone tapping, telephone threats, confiscation of press credentials, closure of the International Press Club in Madrid, MIT infiltration in clandestine press conferences, embargo on the import of foreign newspapers at the airport- were taken by the Ministry of Information and Tourism (MIT) during the late 1970s (Tulloch 2015) they are not comparable to the disciplinary sanctions, fines, bans 
and censorship imposed on national publications -and particularly the magazine market- under the 1966 Press Law, which it must be remembered, was only modified just prior to the first legislative elections of June 1977. The playing field for prodemocratic journalism was then not quite the same on both sides.

\section{Concluding remarks}

Continuity and change. These two words could be employed to summarize the role played by the media during the Spanish transition to democracy. They are, in many ways, words which could also be used to describe the political process itself which, without achieving the democratic break demanded by the Francoist opposition, did culminate in a series of elections regulated by a reform bill approved by the Francoist Lower House before self-dissolution.

The results of the three research projects, concerning the role of the foreign, local and weekly magazine press respectively, offer different profiles of political behaviour which, with some important nuances tend to coincide in one fundamental aspect: the unconditional support for the liberalizing measures of the successive governments of Carlos Arias Navarro and Adolfo Suarez and permanent criticism regarding any actions or measures which cast doubts of the political objectives of the reform or slow the pace, extent and intensity with which they were to be carried out.

Continuity and change can be seen to take place in the three playing fields under analysis. The leading national dailies coming from Francoism maintain a position favourable to the reform proposals while at the same time making quite clear their support towards the conservative agenda headed by Alianza Popular (Manuel Fraga) and the Union de Centro Democratico (Adolfo Suárez). Support for the opposition parties can be found in the new dailies which appeared in 1976 onwards. The general weekly magazines follow a similar pattern although the main difference lies in the fact that the magazines are both quite clearly more open to including the voices and contributions of the democratic opposition and leftwing political groups as well as openly critical of figures and institutions of Francoism. In this sense, many of the new post-1975 press carries the baton originally led by some magazines. This restrained opposition both in press and weeklies is largely due to the control over the press exercised the 1966 Press Law -which was only partially reformed prior to the elections of June 1977- as well as to the precedence/prior employment of many editors and staff writers. This prudent response can also be explained by the uncertainty surrounding the Transition, the resistance shown by the armed forces and the climate of violence generated by ETA as well as extreme right and left political movements. 
Continuity and change is also expressed through the foreign press but this time it is more clearly shown given the greater freedom given to foreign reporters and the political distance with which they were able to approach their work in comparison to their Spanish colleagues. In fundamental issues, the foreign correspondents and columnists coincide with the national press. The nuance here lies in their pragmatic approach -clearly expressed as such-in the context of firm criticism of the nature and legacy of the Francoist regime impossible to find in the Spanish press or their immediate disqualification of the Arias government and the initial reservations regarding the capacity of King Juan Carlos to lead reform as well as a systematic criticism of police repression and the attitude of the Armed Forces.

\section{References}

ANDERSON, L. (1999) Transitions to Democracy. New York: Columbia University Press.

BARRERA, C. (1995) Periodismo y franquismo. De la censura a la apertura. Barcelona: Ediciones Internacionales Universitarias.

CARR, R \& FUSI, J. P. (1993) Spain: Dictatorship to Democracy. Barcelona: Planeta.

CLARK, R. P. \& HALTZEL, M. (1987) Spain in the 1980s. London: Harper Press.

FILGUEIRA, C. \& NOHLEN, D. (1994) Prensa y transición democrática. Experiencias recientes en Europa y América Latina. Madrid: Iberoamericana.

GROSS, P. (2004) Between reality and dream: Eastern European media transition, transformation, consolidation and integration. East European Politics \& Societies. Vol 18 (1). 110-131

GUILLAMET, J. (Ed.) (2014) La Transición Española en la prensa europea y norteamericana. Cuatro miradas: Francia, Italia, Reino Unido y EE.UU. (1975-78). El periodismo en las transiciones políticas. Pp. 111-135. Biblioteca Nueva: Madrid.

GUILLAMET, J. (Ed.) (2016): Las sombras de la Transición. El relato crítico de los corresponsales extranjeros, 1975-1978. Valencia: Publicacions de la Universitat de València.

GUILLAMET, J. (Ed.) (2018): La transición de la prensa. El comportamiento político de diarios y periodistas. Valencia: Publicacions de la Universitat de València. 
JONES, A. (2001) The Press in Transition. A Comparative Study of Nicaragua, South Africa, Jordan and Russia. Hamburg: Deutsches Übersee-Institut.

MARAVALL, J. (1982) The Transition to Democracy in Spain. London: Croom Helm.

McGREW, A. (1997) The Transformation of Democracy? Globalization and Territorial Democracy. London: Wiley.

PRESTON, P. (1986) The Triumph of Democracy in Spain 1969-1982. London: Methuen.

PRIDHAM, G. (1991) Encouraging Democracy. The International Context of Regimen Transition in Southern Europe. Leicester: Leicester University Press.

QUIROSA-CHEYROUZE MUÑOZ. R. (2009) Prensa y Democracia. Los medios de comunicación en la Transición. Madrid: Biblioteca Nueva.

RODRIGUEZ-MARTINEZ, R. AUTHORS 1 AND 2 (2017): Franquismo, monarquía y democracia. La posición política de los principales diarios /ABC, La Vanguardia Española.

TULLOCH, C. (2015) Vigilados: Surveillance of foreign press correspondents during the Spanish Transition to democracy. International Journal of Iberian Studies. Vol. 28. (1) pp. 5-19

TULLOCH, C. (2017) The press platform for moderate change: the discreet role of the Madrid daily Ya during the Spanish Transition. Doxa (24) 87-109. 